\title{
Teaching Reform and Practice of Electrical Automation
}

Yang Li

Shandong Polytechnic College, Jining 272067, Shandong, China.

Abstract: In the new engineering situation, many colleges and universities in China actively promote the "electrical automation teaching reform". In this process, some colleges and universities have achieved outstanding results, while others have been in the exploratory stage. This paper focuses on the "problems existing in the teaching of electrical automation" and "teaching reform and practice of electrical automation", hoping to find out and solve the problems, so as to better promote the teaching reform and practice of electrical automation in colleges and universities in China.

Keywords: Electrical Automation; Problem Analysis; Teaching Reform; Teaching Practice

In the traditional training mode of engineering talents, some colleges and universities are easy to ignore students' practical ability, innovative spirit and comprehensive quality, due to the limitation of by teaching resources, teaching methods, teaching assessment and many other practical factors, which is not conducive to the all-round development of students. With the new engineering as the guidance direction, many colleges and universities in China have begun to actively promote the "electrical automation teaching reform", hoping to further strengthen students' practical ability, cultivate their innovative spirit, and export more and more comprehensive quality electrical professionals for the society. At present, the teaching reform of electrical automation in some colleges and universities in China has made great progress. However, from the national perspective, there are still some deficiencies in the teaching of electrical automation in some colleges and universities, which requires comprehensive and systematic reform.

\section{Problems in electrical automation teaching}

\subsection{Unreasonable course setting}

At present, the prominent problem in the teaching of electrical automation in some colleges and universities in China is "unreasonable course setting". This unreasonable setting is reflected in many aspects. Specifically speaking, on the one hand, in the electrical automation teaching, the course content set by some colleges and universities often intersect and overlaps with the course content of relevant majors, which leads to students' confusion and difficulty in distinguishing in the learning process. In this case, students' overall perception of electrical professional knowledge will be relatively weak, especially for some students, whose foundation is not very good, are more difficult to understand the content of the course; on the other hand, in the teaching of electrical automation, some colleges and universities set the course content by fixed formwork without significant adjustment every year. With the development of society, there are a lot of new knowledge and technology in the electrical industry $^{[1]}$. It is not only difficult to attract the attention of students, but also not conducive to improving the professional ability of students if the market demand and optimize the course content is not combined by the schools. The students will find out that the knowledge they have learned is far from the actual needs when they are employed.

Copyright(C) 2020 Yang Li

doi: 10.18686/ahe.v4i10.2897

This is an open-access article distributed under the terms of the Creative Commons Attribution Non-Commercial License (http://creativecommons. org/licenses/by-nc/4.0/), which permits unrestricted non-commercial use, distribution, and reproduction in any medium, provided the original work is properly cited. 


\subsection{Imperfect practice teaching system}

In electrical automation teaching, practice teaching often occupies a very important position. Now, the practice teaching system in some colleges and universities is not perfect, mainly in the following aspects: first, in the electrical automation teaching, although some teachers have set up the practice teaching, the practical teaching hours are not much compared with the theoretical teaching, without highlighting its importance. This is an important reason for the lack of practical application ability of students majoring in electrical engineering, and it is also an important content of electrical automation teaching reform in many colleges and universities in China. Second, in the teaching of electrical automation, some teachers tend to have fixed thinking patterns in the design of practical teaching, and limit practical teaching to campus only ${ }^{[2]}$. Based on this thinking pattern, teachers will miss many practical opportunities of school enterprise cooperation, which is not conducive to expanding students' practice path. In order to further improve the practical teaching system, teachers need to have new ideas and perspectives on practical teaching design.

\subsection{Lack of innovation and entrepreneurship education}

In the connotation of new engineering, innovation and entrepreneurship education is an important force to help students become talents. Recently, the lack of innovation and entrepreneurship education in some colleges and universities in China is mainly reflected in these aspects: on the one hand, in the electrical automation teaching, some teachers overemphasize professional knowledge and professional skills, and fail to reasonably integrate "innovation" into each teaching link, resulting in the lack of innovation consciousness and spirit for students. In the face of increasingly fierce employment competition, the lack of innovative spirit makes students in weak employment competitiveness; on the other hand, in the teaching of electrical automation, some teachers have no practical path for the implementation of innovation and entrepreneurship education. The reason for this problem is related to teachers' awareness of innovation and entrepreneurship education and school resources ${ }^{[3]}$. The implementation of innovation and entrepreneurship education needs the active cooperation of various forces. Some resistance will be brought to teachers, if the regulatory role is not played by the school for optimal allocation of resources.

\section{Teaching reform and practice of electrical automation}

\subsection{Reasonable setting of electrical automation course}

In the process of promoting the teaching reform and practice of electrical automation, reasonable setting of electrical automation course is to lay a good foundation for the reform. More concretely, on the one hand, in the electrical automation teaching, the course content set by the school should avoid intersecting and overlapping with the course content of relevant majors. Schools can organize relevant professional teachers to hold "course seminar", so that each professional course can highlight the professional attribute. In this way, teaching can be optimized, and students' understanding of the connotation of the course can be improved; on the other hand, in the teaching of electrical automation, the course content set by the school should not only have the "traditional" part ${ }^{[4]}$, but also have the part of "keeping pace with the times", so as to continuously optimize the course content. Schools can make certain demands on teachers, hold "new knowledge sharing lectures in electrical fields" and "new technology forum in electrical field" regularly. ${ }^{[5]}$ This is not only a part of campus activities, but also a way to improve teachers' professional ability, which is conducive to maintaining the advanced nature of electrical automation teaching.

\subsection{Improving the practical teaching system of electrical automation}

How to further improve the practical teaching system of electrical automation? Specifically, first, in the electrical automation teaching, teachers should reasonably set the proportion of "theoretical teaching" and "practical teaching". For some practical courses, teachers should focus on the importance of practical teaching, in order to better promote it. Meanwhile, the school can further improve the "construction of electrical automation practice base", introduce advanced equipment and instruments, and build a multi module and multi-level practical teaching system, so that every student has better conditions for practical learning; second, in the teaching of electrical automation, teachers should have the courage to break away from the tradition in the design of practical teaching and give full play to the advantages of off campus training. Teachers can further deepen "school enterprise cooperation" and "cooperation between schools" to create more opportunities for students 
to practice learning. In this process, the school offers human and material support to carry out long-term planning for school enterprise cooperation and cooperation between schools.

\subsection{Strengthening the innovation and entrepreneurship education of electrical automation}

Under the background of new engineering, strengthening the innovation and entrepreneurship education of electrical automation is in line with the teaching reform trend of electrical specialty. Specifically, on the one hand, in the teaching of electrical automation, teachers should not only teach professional knowledge and professional skills, but also reasonably integrate innovation and entrepreneurship education, especially to make students realize the importance of "innovation". In the form of "electrical automation creative competition", schools can stimulate students' innovative potential and enable them to establish the learning goal of "taking innovation as pride"; on the other hand, in the teaching of electrical automation, teachers should actively strive for the cooperation and support of various forces for the implementation of innovation and innovation education. For example, teachers combine the overall resources of the school to integrate innovation and entrepreneurship education into campus life through community activities, Party building activities, exchange activities between schools and so on, so that students can realize that the spirit of innovation and entrepreneurship is everywhere, forming an innovative and entrepreneurial atmosphere inside the school. Another example, teachers combine the resources of schools and enterprises to build a distinctive innovation and entrepreneurship education system, including talent training program, training base construction, enterprise practice, assessment mechanism, etc., to create an innovation and entrepreneurship platform of "integration of production and education".

\section{Conclusion}

With the development of society, electrical automation professional knowledge involves many fields, related to the construction and development of many emerging industries. In order to explore the teaching reform and practice of electrical automation, we should not forget the original intention and build a car behind closed doors. The meaningful, targeted and effective reform should be carried out according to the actual situation. In this process, the relevant teachers should constantly break their traditional thinking pattern, improve themselves with an open and enterprising attitude, in order to infect and convey confidence to students, and cultivate more electrical automation professionals with higher quality for our country.

\section{References}

1. Zhu Y. Exploration on practice teaching reform of electrical engineering and automation specialty in higher vocational colleges. Science and Technology Economic Guide 2019; (24): 173.

2. Guo Y. Exploration and thinking on practical teaching of electrical engineering and automation specialty. Information System Engineering 2019; (5): 172.

3. Chennd X, Ren G, Lu B. Reform and practice of talent training mode for electrical engineering and automation specialty. Laboratory Science 2017; (6): 231-233+236.

4. Bai Y, Liu C, Ai X, et al. Challenges and countermeasures of traditional engineering majors under the background of engineering education reform-The empirical investigation of training program of ten universities based on training program of "Electrical Engineering and Automation”. Higher Engineering Education 2018; (3): 53-62.

5. Luan G, Li A, Wang D, et al. Thinking on talent training of electrical engineering specialty in local colleges and universities under the background of new engineering. Heilongjiang Education (Theory and Practice) 2018; (4): 4-5.

6. Zhou Y, Wang Y, Wang L. Research and practice of talent training mode of electrical engineering and automation specialty under the background of new engineering. Education Modernization 2019; 6(59): 6-8. 